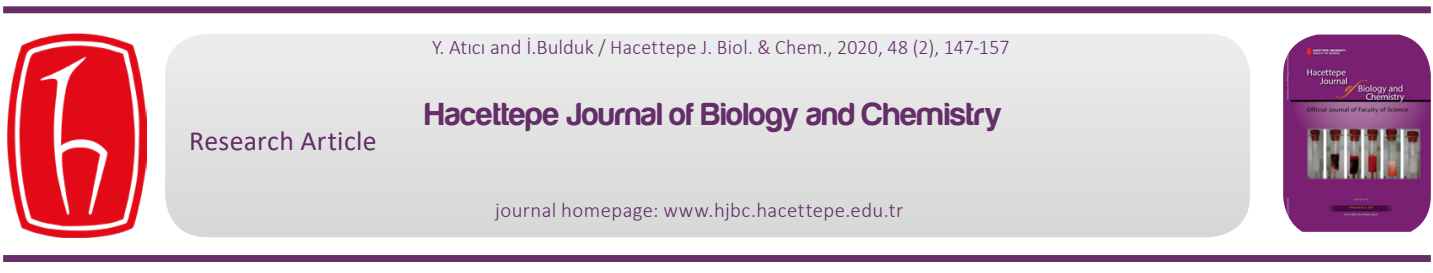

\title{
Optimization the Ultrasonic Assisted Extraction of Chlorogenic Acid from the Artichoke (Cynara Scolymus) Leaf with Response Surface Methodology and Total Phenolic Contents
}

\section{Enginar (Cynara Scolymus) Yapraklarından Klorojenik Asitin Ultrasonik Destekli Ekstraksiyonunun Yüzey Yanıt Metadolojisi ile Optimizasyonu ve Toplam Fenolik İçerikleri}

\author{
Yakup Atıci ${ }^{1 *}$, ibrahim Bulduk ${ }^{2}$ \\ ${ }^{1}$ Chemical Engineering, Istanbul University, Istanbul, Turkey. \\ ${ }^{2}$ Usak Health Training School, Usak University, Usak, Turkey.
}

\section{A B STRACT}

\begin{abstract}
rtichoke leaf (Cynara Scolymus) extracts are widely used in medicine. Chlorogenic acids are the compounds which have antioxiAdant, antibacterial and antiviral properties. In this study, after the artichoke (Cynara scolymus) leaves were dried, the powdered portions were extracted with water. Extracts were analyzed by HPLC and the results were expressed as ppm. The optimum conditions for extracting chlorogenic acid from Cynara Scolymus were determined by ultrasonic assisted extraction using the Surface Response Method based on Box-Behnken design. The experimental conditions of extraction were determined as extraction time (15-45 minutes), temperature $\left(30-70^{\circ} \mathrm{C}\right)$ and ultrasonic power $(25-75 \%)$. The optimum conditions were determined as $47.65 \%$ ultrasonic power, 35.18 minutes, $53.40^{\circ} \mathrm{C}$ temperature. The maximum yield of chlorogenic acid was determined as $10.05 \mathrm{ppm}$. Also the total phenolic content was measured by UV -Vis spectrometry in order to see antioxidant activity. Absorbance values of the samples which were taken from each samples were measured at $765 \mathrm{~nm}$ in UV spectrometer. Optimum conditions were determined as $47.29 \%$ ultrasonic power, 29.67 minutes, 55.33\% ethanol concentration. Total phenolic content were determined as $70.24 \mathrm{ppm}$. According to the obtained results, ultrasonic-assisted extraction (UAE) can be an effective method for the extraction of chlorogenic acid active ingredient.
\end{abstract}

\section{Key Words}

Chlorogenic Acid, Artichoke leaf (Cynara scolymus), Extraction, Optimization, RSM.

\section{öz}

\begin{abstract}
— nginar yaprağı (Cynara Scolymus) ekstratları tıpta yaygın olarak kullanılan özlerdir. Klorojenik asitler antioksidan antibakteriyel ve an- tiviral özelliklerine sahip bileşiklerdir. Bu çalışmada, enginar (Cynara scolymus) yaprakları kuruduktan sonra, toz halindeki kısımlar su ile ekstre edilmiştir. Özler, HPLC (Yüksek Basınçı SIvı Kromatografisi) ile analiz edildikten sonra ppm olarak ifade edilmiştir. Box-Behnken tasarımına dayalı Yüzey Yanıt Yöntemi kullanılarak, klorojenik asidin Cynara Scolymus'tan ekstrakte edilmesinin optimum koşulları, ultrasonik destekli ekstraksiyon ile tespit edilmiştir. Bu ekstraksiyon etkinliği için deneysel koşullar, ekstraksiyon süresi (15-45 dakika), sıcaklık $\left(30-70^{\circ} \mathrm{C}\right)$ ve ultrason gücü (\%25-75) olarak belirlenmiştir. Optimum koşullar \%47.65 ultrason gücü, 35.18 dakika, $53.400 \mathrm{C}$ sıcaklık olarak belirlenmiştir. Sonuçta ise maksimum klorojenik asit verimi 10.05 ppm olarak belirlenmiştir. Ayrıca toplam fenolik içerik yani antioksidan kapasitesi ise UV-Vis spektrometresi ile ölçülmüştür. Her bir numuneden alınan numunelerin absorbans değerleri UV spektrometresinde 765 nm'de ölçülmüştür. Optimum koşullar \%47.29 ultrason gücü, 29.67 dakika, \%55.33 etanol konsantrasyonu olarak belirlenmiştir. Toplam fenolik içerik 70.24 ppm olarak belirlenmiştir. Sonuçlara göre ultrasonik yardımlı ekstraksiyon (UAE), klorojenik asit ekstraksiyonu için etkili bir yöntem olabileceğini göstermiştir.
\end{abstract}

\author{
Anahtar Kelimeler \\ Klorojenik Asit, Enginar (Cynara scolymus), Ekstraksiyon, Optimizasyon, RSM.
}




\section{INTRODUCTION}

hlorogenic acid is a compound that naturally present in leaves, seeds and roots of the plant. The most common known source of chlorogenic acid are coffee, artichoke leaf, ash leaf, apricot leaves, eggplant, plum and kiwi [1]. Researchs continues to produce large amount and high purity chlorogenic acid day to day.

Particularly the pharmaceutical industry is concerned with cost-effective and environmentally friendly production methods. Chlorogenic acid is not produced in our country and are imported both as a medicament and the form of drug [2]. Easily applicable a method development for isolating chlorogenic acid from the plant leaves and purification is considered that important devolopment for our country pharmaceutical and chemical industry [3]. Natural chlorogenic acid that derived from plants produce by traditional solvent extraction process. Toxic chemicals which will negatively affect the environment and human health are used in conventional manufacturing methods. Production times are long and high costs at traditional methods [4].

Ultrasonic assisted extraction is alternative to extraction techniques that are inexpensive, simple conventional. However, regarding artichoke leaf extraction procedure is not widely available. Extraction method should be designed and optimized. Solvent type, solvent concentration, the solid/solvent ratio, extraction temperature, extraction time and ultrasound power for extraction are operation parameters that affect industrial processes. It should be considered that possible interactions between other operating parameters to optimize the process [5].

Response surface methodology (RSM) are taken into account possible interactions between the operating parameters. RSM is a combination of statistical and mathematical techniques used for process optimization. Box and Wilson was personeles first used response surface methodology for impacts on the various processes [6].

Consequently, the response surface methodology is the sum of mathematical and statistical techniques to process successfully used. The main advantage is reduce the number of experiments needed to evaluate multiple parameters. Response surface methodology have been used successfully to optimize biochemical and biotechnological processes related with the extraction of phenolic components of food items [7].

\section{MATERIALS and METHODS}

\section{Used Material}

Artichoke leaves that used in the experiment studies were collected in the spring months. Leaves were collected from Trakya Region in 2013 and dried for one month in the dark room at room temperature. Dried leaves were milled to 80-100 mesh particle size range by robot before extraction.

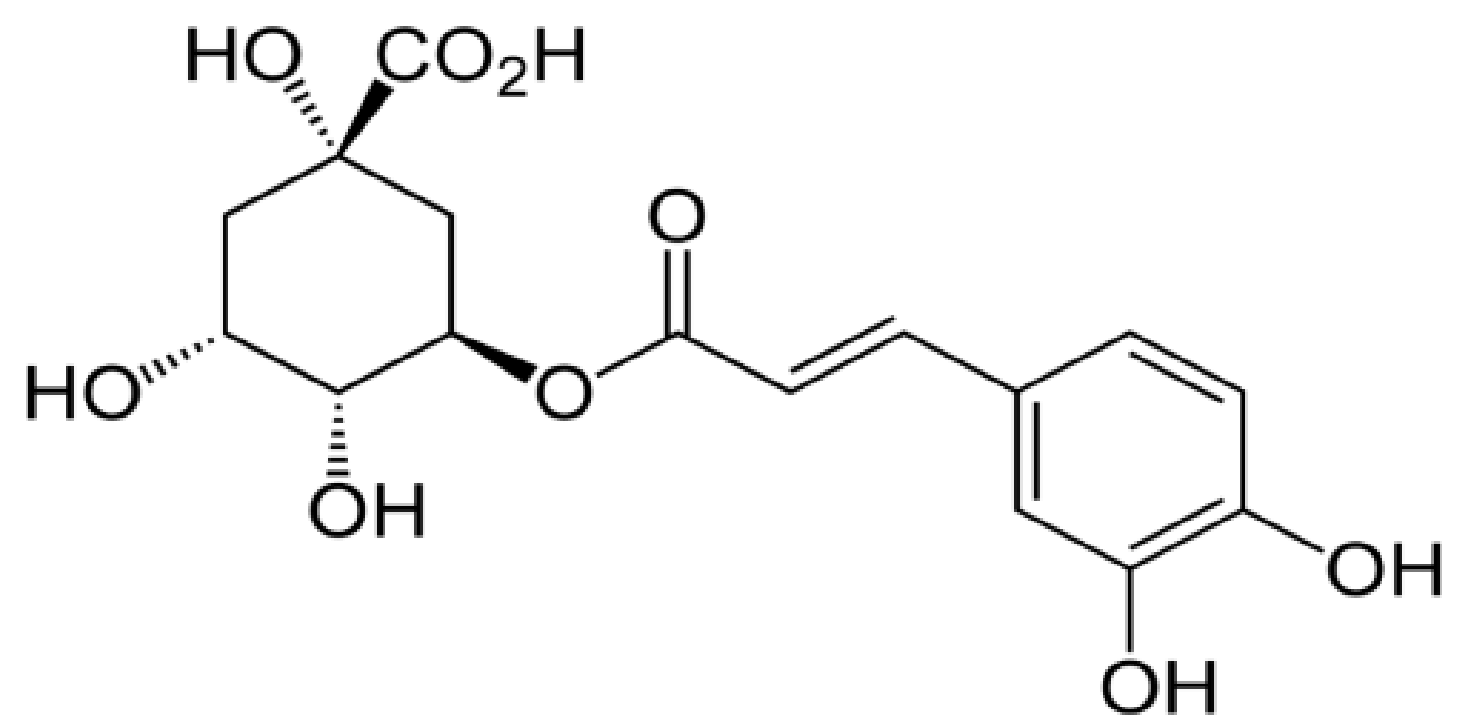

Figure 1. Chemical structure of chlorogenic acid. 
Table 1. The results obtained from the testing of different parameters during the validation of the analytical method.

\begin{tabular}{ccc}
\hline Parameters & & Chlorogenic Acid \\
\hline Linearity & Range of concentrations (ppm) & $20-100$ \\
\hline & Correlation Coefficient & 0.9999 \\
\hline & Glide & 4.526 \\
\hline LOD $(\mathrm{ppm})$ & Slope & 6.4094 \\
\hline LOQ $(\mathrm{ppm})$ & & 0.076 \\
\hline Retention time $(\mathrm{min})$ & & 0.254 \\
\hline
\end{tabular}

Table 2. Values and symbols of the independent variables.

\begin{tabular}{cccccc}
\hline \multicolumn{2}{l}{ Values and symbols of independent variables } & & & \\
\hline Independent Variable & Units & Symbol of variable & \multicolumn{2}{c}{ Code Level } \\
\hline & & & -1 & 0 & 1 \\
\hline Ultrasound Power & $\%$ & $\mathrm{~A}$ & 25 & 50 & 75 \\
\hline Extraction Time & $\mathrm{min}$ & $\mathrm{B}$ & 15 & 30 & 45 \\
\hline ExtractionTemperature & ${ }^{\circ} \mathrm{C}$ & $\mathrm{C}$ & 30 & 50 & 70 \\
\hline
\end{tabular}

All reagents used in the experiments are analytical purity and chemicals which used in analysis are HPLC grade purity. Methanol, ammonia, glacial acetic acid, hydrochloric acid, chlorogenic acid standard and sodium hydroxide were purchased from Sigma-Aldrich. Deionized water that is obtained from Millipore Milli-Q Water Purification System $<18 \mathrm{m \omega}$ was used as solvent. Membrane filters that is the size $0,45 \mu \mathrm{m}$ (Millipore, Bedford, MA, USA) were used for filtration of buffer.

\section{Ultrasonic Assisted Extraction}

Ultrasonic assisted extraction which performed at 50 $\mathrm{kHz}$ frequency did at ultrasonic Bandelin Sonorex bath brand. Dried and milled artichoke leaves which weighed $500 \mathrm{mg}$ put in erlenmayer.

Pure water added as $30 \mathrm{ml}$ solution. Water temperature controlled with ice. The erlenmayer sealed with aluminum foil and placed within the bathroom. Solvent level in the erlenmayer and the water level in the ultrasonic bath kept the same. Ultrasound power, temperature and time values specified in the table set the device and operated. After extraction had completed, the solution filtered both the Whatman brand filter paper and 0.45 micron membrane of the filter in order to prevent clogging of the capillary.

\section{The Chromatographic Conditions (HPLC Method)}

Identification Chlorogenic Acid in extracts and determining the amount was made with Agilent 1260 Chromatographic System which is contain autosampler, quaternary pump, column furnace, UV detector and a Base-Deactivated octadecylsilyl Silica Gel, $5 \mu \mathrm{m}, 4.0$ x $250 \mathrm{~mm}$ column. Mobile Phase A: 15\% methanol + 85\% $\mathrm{ml}$ of water was prepared. $\mathrm{pH}$ is adjusted to 2 with dilute phosphoric acid solution.

Mobile Phase B: pure methanol. Injection Volume is 20 $\mathrm{mL}$. Column Temperature is $30{ }^{\circ} \mathrm{C}$. Detection is at 330 $\mathrm{nm}$. Flow rate is $1 \mathrm{ml} / \mathrm{min}$. Time Analysis is $36 \mathrm{~min}$.

\section{HPLC Analysis Method Validation Studies}

In analysis of the validation exercise standard solutions were prepared that using powder form chlorogenic acid standard of 20 ppm, 40 ppm, 60 ppm, 80 ppm and 100 ppm provided in Sigma Aldrich.

Each of these standard solutions was performed five times injection in HPLC device. By using the peak areas in the chromatograms obtained, intra-day and inter-day repeatability, calibration linearity and reproducibility tests were performed, concentration range, correlation coefficient, shift, slope, diagnostic limit value (LOD), determination limit value (LOQ) and retention time were determined. 
Table 3. Values and symbols of the independent variables.

\begin{tabular}{ccccc}
\hline Experiment No. & Ultrasound Power $(\%)$ & Time $(\mathrm{min})$ & Temperature $\left({ }^{\circ} \mathrm{C}\right)$ & $\begin{array}{c}\text { Chlorogenic } \\
\text { Acid Yield }\end{array}$ \\
\hline $\mathbf{1}$ & 50 & 45 & 70 & 8.66 \\
\hline $\mathbf{2}$ & 25 & 30 & 70 & 6.53 \\
\hline $\mathbf{3}$ & 50 & 30 & 50 & 9.83 \\
\hline $\mathbf{4}$ & 75 & 15 & 50 & 5.4 \\
\hline $\mathbf{5}$ & 25 & 30 & 30 & 2.45 \\
\hline $\mathbf{6}$ & 25 & 15 & 50 & 3.73 \\
\hline $\mathbf{7}$ & 50 & 15 & 30 & 6.3 \\
\hline $\mathbf{8}$ & 75 & 45 & 50 & 8.56 \\
\hline $\mathbf{9}$ & 50 & 30 & 50 & 9.27 \\
\hline $\mathbf{1 0}$ & 50 & 30 & 50 & 4.35 \\
\hline $\mathbf{1 1}$ & 75 & 30 & 70 & 9.97 \\
\hline $\mathbf{1 2}$ & 50 & 30 & 50 & 4.26 \\
\hline $\mathbf{1 3}$ & 50 & 45 & 30 & 3.24 \\
\hline $\mathbf{1 4}$ & 75 & 30 & 30 & 4.98 \\
\hline $\mathbf{1 5}$ & 50 & 15 & 70 & 7.6 \\
\hline $\mathbf{1 6}$ & 25 & 45 & 50 & 9.71 \\
\hline $\mathbf{1 7}$ & 50 & 30 & 50 & \\
\hline & & & & \\
\hline
\end{tabular}

\section{Determining The Amount of The Total Phenolic Compounds}

Leaves of the sample which is dried in a dark room was grinded to a grain size of 80 mesh at laboratory scale mill. $1 \mathrm{~g}$ of sample from which was the milled and dried was weighed and which was transferred into a $200 \mathrm{~mL}$ flask. $50 \mathrm{ml}$ (70\% methanol $+30 \%$ demineralized water) the extraction solvent was added in flask. Extraction was carried out continuously at ultrasonic bath for 30 minutes. After extraction completion the extract was filtered with a white band filter paper. Extracts were stored in a refrigerator until analysis. Determination of total phenol content in the extracts was performed by the Folin Ciocaltaeu Method. Gallic acid used as standard, the phenolic content was provided as gallic acid equivalents. In method, $250 \mu \mathrm{l}$ Folin Folin Ciocaltae Phenol Reagent was stirred with $50 \mathrm{~mL}$ extract and added to $500 \mu \mathrm{l}$ sodium carbonate solution mixture. The volume made up to $5 \mathrm{ml}$ with demineralized water.

After which was stand for half an hour in a dark room,) absorbance of sample was measured in a spectrophotometer (PerkinElmer Lambda 35 brand model UV-VIS Spectrophotometer) at wave length $765 \mathrm{~nm}$. Total phenolics content was calculated from that is measured absorbance value as Gallic acid value equivalent.

\section{RESULTS and DISCUSSION}

\section{The Linearity of Analytic Method}

Calibration linearity obtained through peak area that is obtained versus five different concentrations by charting. Five injections were performed from 20 ppm, 40 ppm, 60 ppm, 80 ppm, 100 ppm standard solutions for calibration of the device.

\section{Optimization of Ultrasonic Assisted Extraction with The Response Surface Method}

Individual effects of the known process variables simultaneously as a single factor approach was applied in the previous section. This the classical approach ignores the possibility of interaction with each process variable. The response surface methodology take into account possible interaction between operating parameters. Schedules shows including three parameters; minimum, medium, maximum (ultrasound power, time and temperature).

17 trials were studied and were randomly selected by the expert design software and the responses were recorded. The quadratic model was obtained for efficiencies the extraction but only step to step forward also 


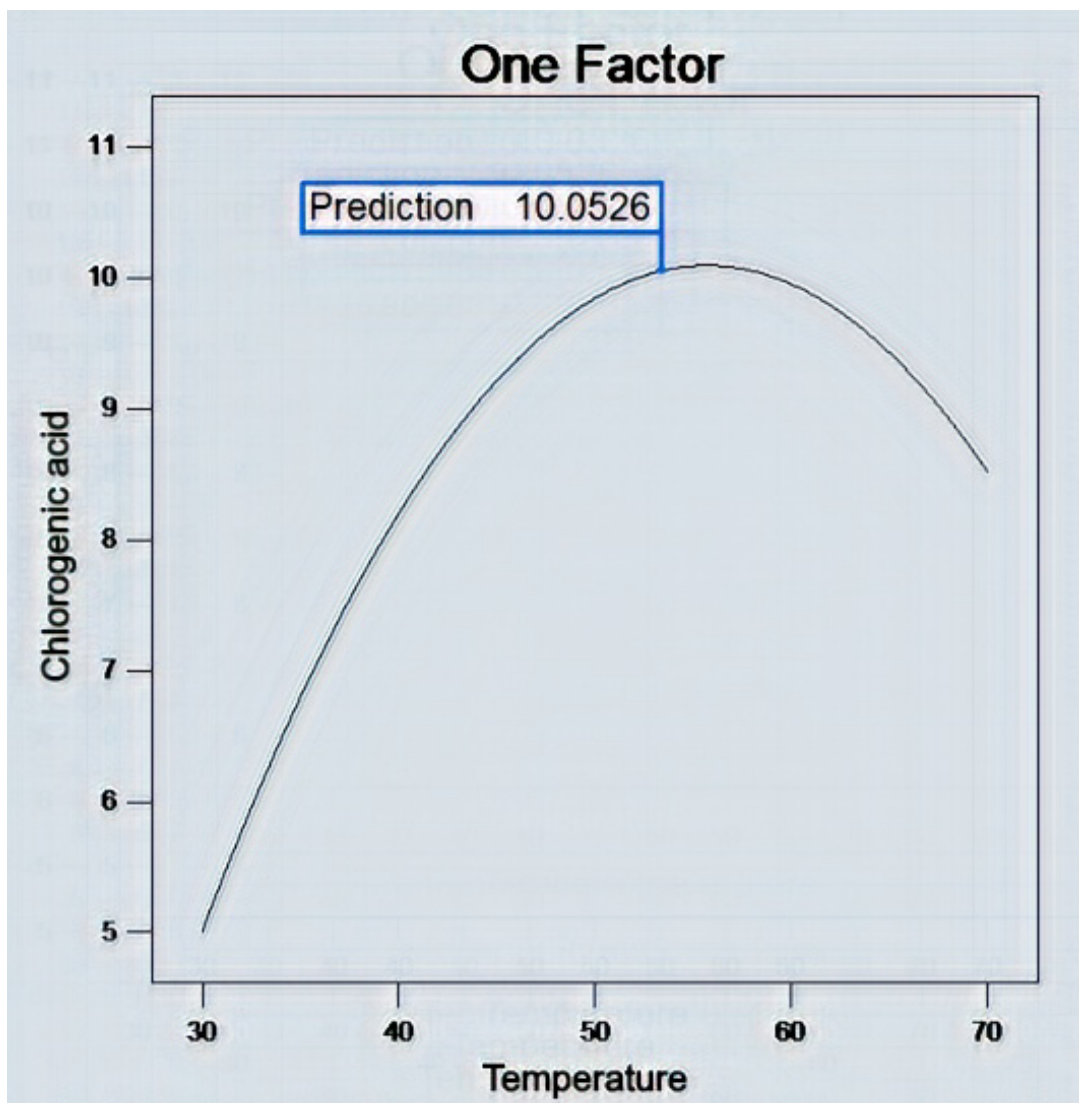

Figure 2. The change yield of chlorogenic acid which is derived artichoke leaves with extraction temperature.

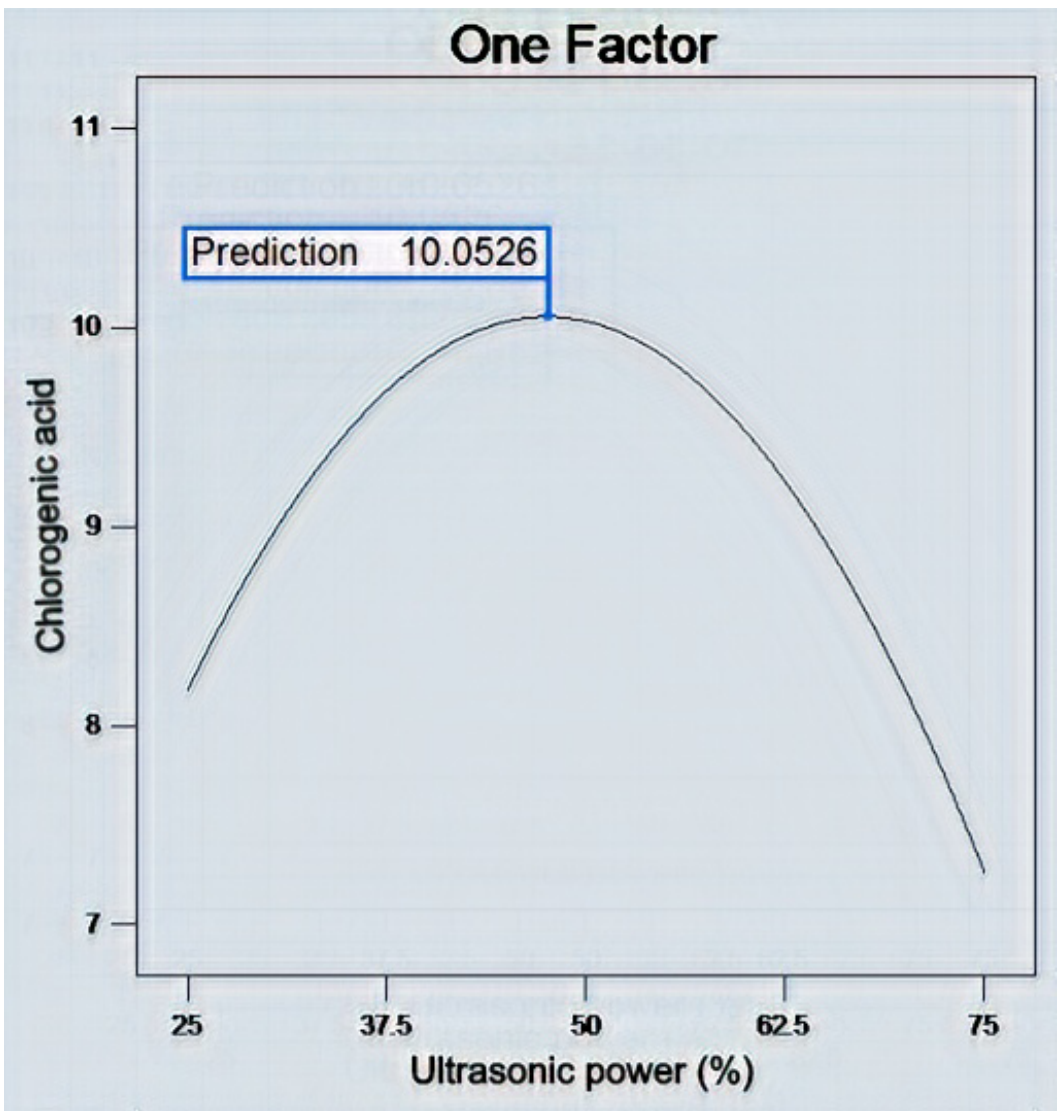

Figure 3. The change yield of chlorogenic acid which is derived artichoke leaves with ultrasound power. 


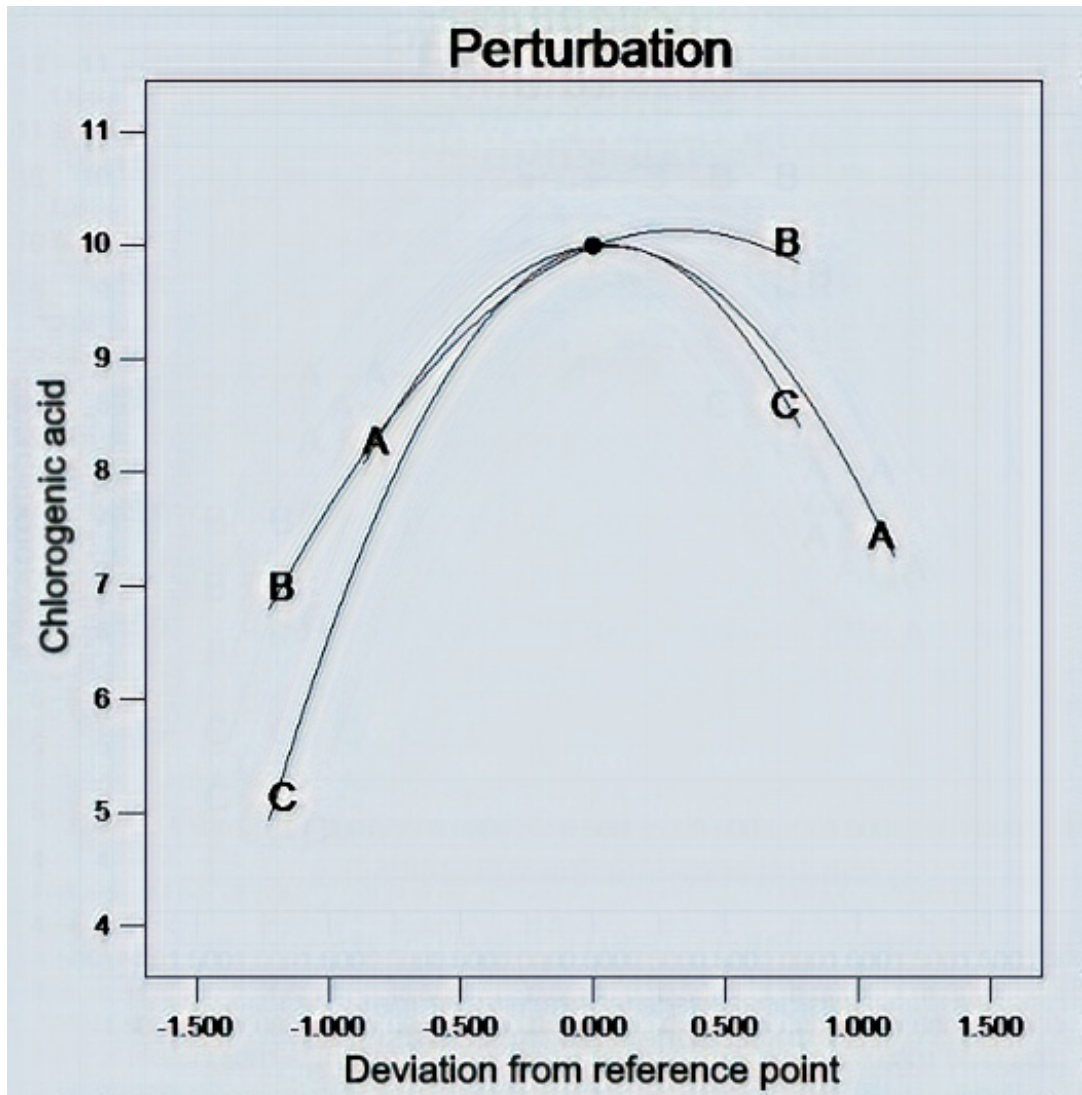

Figure 4. The change yield of chlorogenic acid which is derived artichoke leaves with all variables. (A Ultrasound power B: time C: temperature)

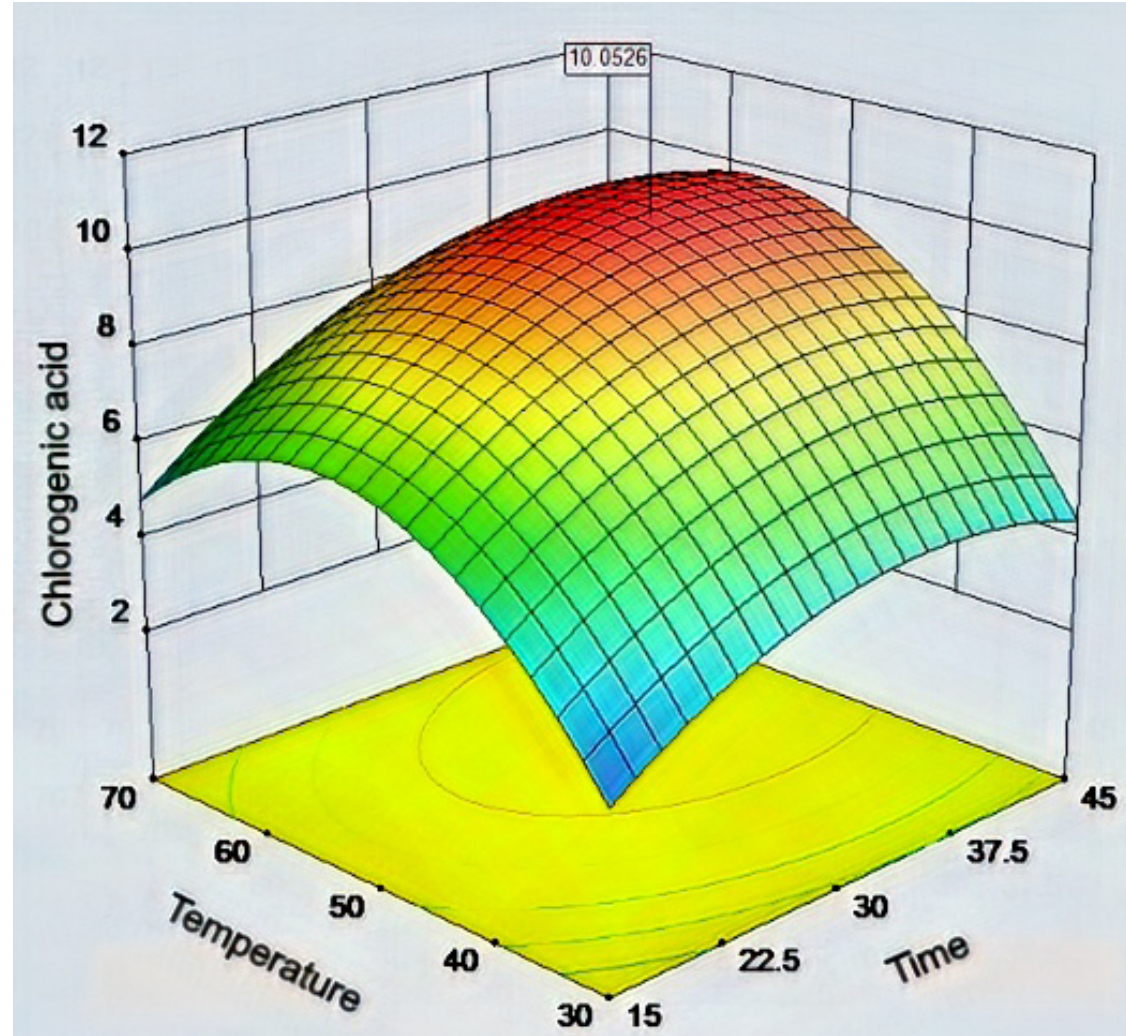

Figure 5. Response surface graph for yield chlorogenic acid which is derived artichoke leaves as a function of time ratio to extraction temperature. 


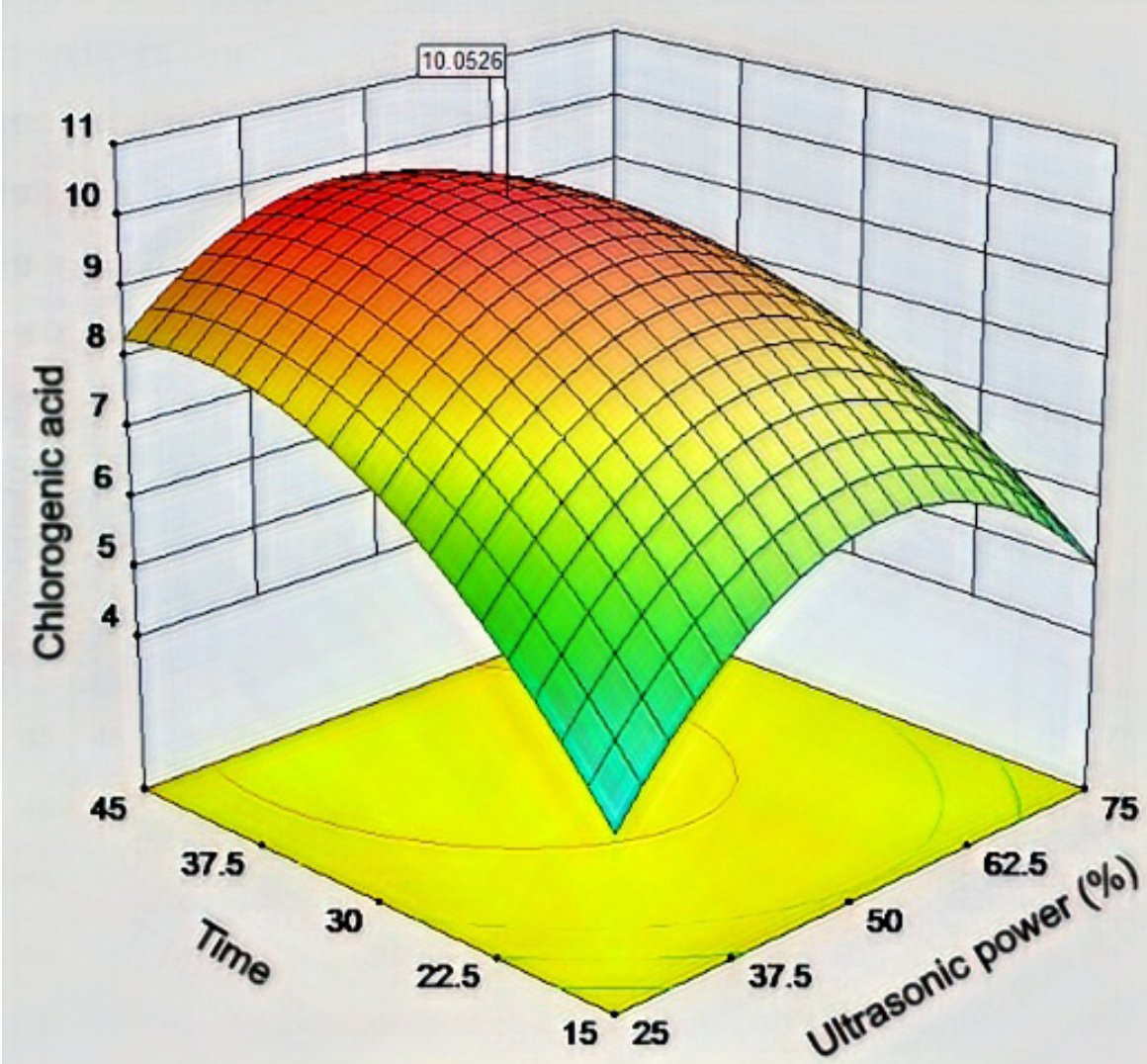

Figure 6. Response surface graph for yield chlorogenic acid which is derived artichoke leaves as function of extraction time ratio to ultrasound power.

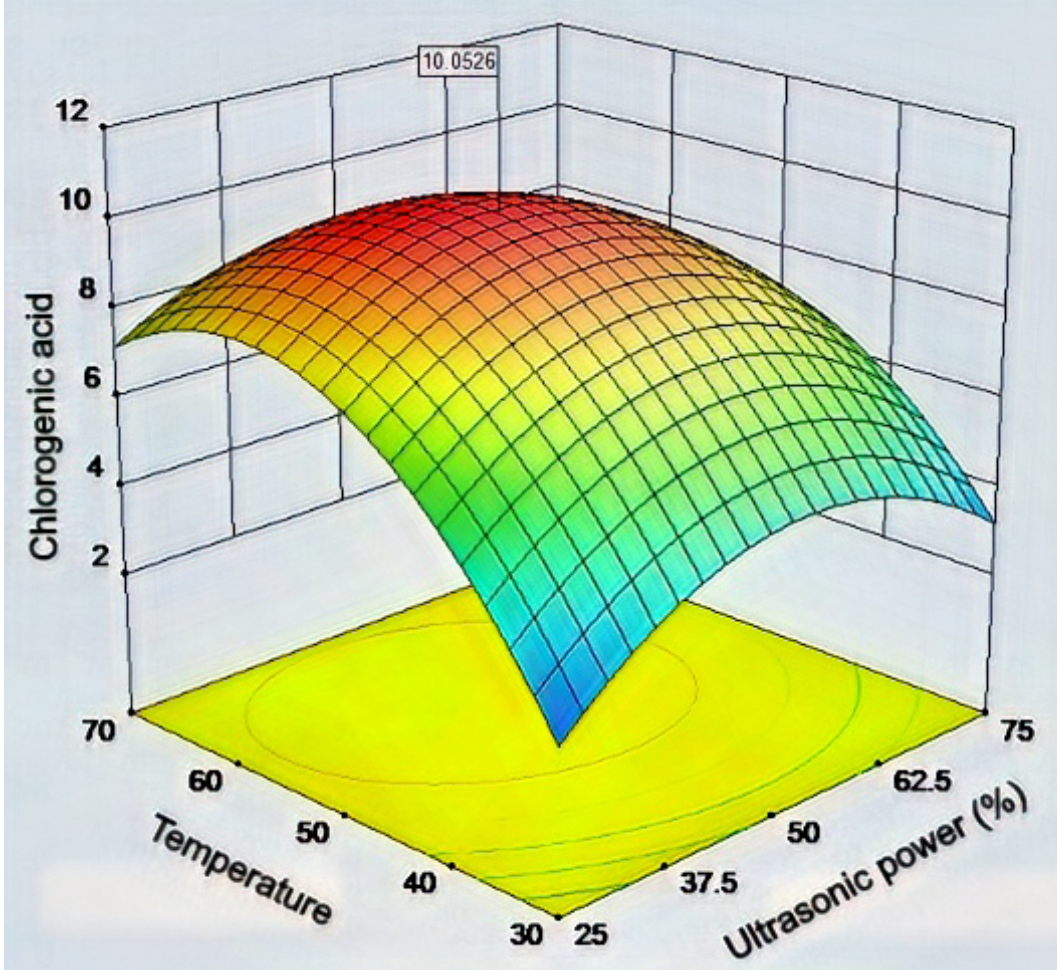




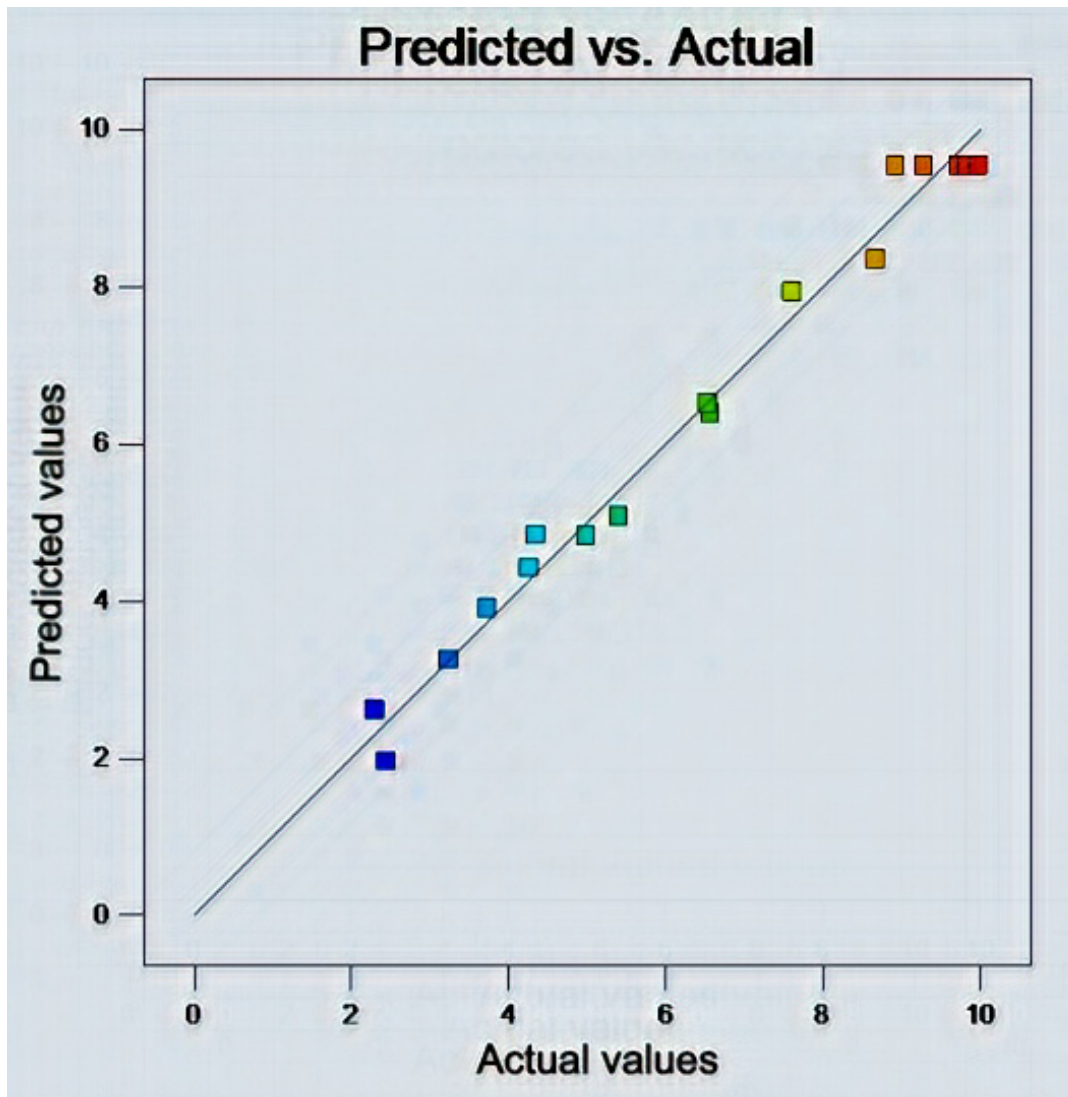

Figure 8. Comparison of the experimental data with the values obtained from the equation for the artichoke leaf.

but also practicing destroy back. A quadratic model was obtained by using response surface method

\section{Chlorogenic acid to artichoke leaf:}

$35.19562+0.49465 \times A+0.48225 \times B+0.87919 \times C-1.806$ $\times 10^{3} \times A \times B-1.48 \times 10^{3} \times A \times C+1.43 \times 10^{3} \times B \times C^{-3} .70 \times 10^{3}$ $\times A^{2}-6.24 \times 10^{3} \times B^{2}-7.71 \times 10^{3} \times C^{2}$

\section{A: Ultrasound Power, B: time C: The temperature}

Optimum extraction conditions was found by using optimization design expert software. The optimum condition values for artichoke (Cynara Scolymus) leaves was determined that $47.65 \%$ the ultrasound power, 35.18 minutes extraction time, $53.40^{\circ} \mathrm{C}$ extraction temperature. Under these conditions, the maximum yield of chlorogenic acids was determined to be $5.10 \mathrm{ppm}$. After the optimal conditions was found and the actual sample extraction experiments had repeated 3 times and relative standard deviation average had calculated.
Average 9.8553

Standard Deviation: 0.015

Relative Standard Deviation: 0.435

Chlorogenic Acid Yield (mg/500 mg samples): $9.8553 \pm$ 0.015

Results is suitable for the statistical analysis.

\section{Model fitting}

The analysis of variance (ANOVA) for the quadratic equations of Design Expert 8.0.7.1 for the responses are given in Table 4. In order to have the most suitable set of variables, stepwise regression was used. According to this process, given variables are tested and assessed within the given alpha levels (0.1) using both backward and forward techniques. Backward techniques include all the variables to estimate parameters, and then any variables with a non significant parameter at alpha levels are removed from the equation.

This process continues until there are no significant variables left. Similar to backward technique, forward technique also assess the given variables within the given alpha levels. Unlike backward technique, forward technique starts with no variables included in the equ- 
Table 4. Anova table artichoke leaf.

\begin{tabular}{cccccc}
\hline Source & Sum of Squares & DF & Squares Mean & FValue & $\begin{array}{c}\text { PValue } \\
\text { polasilik> F }\end{array}$ \\
\hline Model & 116.15 & 9 & 33573 & 51.38 & $<0.0001$-Ultrasound \\
\hline Gc & 72 & 1 & 72 & 0,020139 & 0.6085 \\
\hline B-Time & 0,599305556 & 1 & 0,599305556 & 56.66 & 0.0001 \\
\hline C-Temp & 18.82 & 1 & 18.82 & 74.92 & $<0.0001$ \\
\hline EU & 30682 & 1 & 30682 & 11505 & 0.0305 \\
\hline AC & 22100210 & 1 & & 28703 & 44228 \\
\hline BC & 0.740 .1299 & 1 & 34366 & 0.74 \\
\hline a $^{2}$ & 22.52 & 1 & 22.52 & 39.64 & $<0.0001$ \\
\hline B & 11536 & 1 & 11536 & 2 & 0.0007 \\
\hline C 159.54 & 40.07 & 1 & 40.07 & - & $<0.0001$ \\
\hline Residuals of & 27760 & 7 & 0,517361111 & 28126 & - \\
\hline The lack of cohesion & 0,041666667 & 3 & 0,022916667 & - & 0.2915 \\
\hline Error & 0.76 & 4 & 0.19 & - & -
\end{tabular}

ation. The significant variable with the highest value of standardized beta $(p<0.05)$ will be added to the equation. Then the next variable with the highest standardized beta value is assessed. If the variable is significant, it is added to the equation.

This process continues until no significant variables left [8-9]. In our study, the model derived for R-Square (0.9650) was used for extraction yields; Adj R Square (0.9200) and Pred R Square (0.7325) were obtained. And these values show the sensitivity of the derived model. Ultimately, the extraction yield of ash leaves by ultrasonically supported extraction can be achieved by surface response modeling. The coefficient of variation (C.V.\%) was also determined as 5.70. This low variation value demonstrates the reliability and high sensitivity of experimental results [12].

\section{Total Phenolic Content}

Total phenolic contents of artichoke leaves were analyzed by UV spectrometer to determine the antioxidant capacity at the second phase of the study. Optimum conditions for the artichoke leaves; ultrasound power 47.29\%, 29.67 min period, ethanol concentration was determined as $55.33 \%$. The total phenolic content of artichoke leaves was determined as 70.24 ppm in optimum conditions.

\section{CONCLUSION and DISCUSSION}

In the first stage of this study, method optimization was performed for the determination of chlorogenic acid from ash tree leaf and artichoke leaf by HPLC (High Pressure Liquid Chromatography). In this study, artichoke leaves were used as research material as potential sources of chlorogenic acid.). The dried leaves were extracted with ultrasonic assisted extraction method. The ultrasonic assisted extraction method is advantageous and environmentally friendly in comparison with traditional extraction methods because of being used less solvent and being performed in a short time [10-11]. The optimum conditions for artichoke (Cynara Scolymus) leaves were determined as ultrasonic power was 47.65\%, extraction time was 35.18 minutes, the extraction temperature was 53.40 [C. Maximum chlorogenic acid yield was determined as 10.05 ppm, under the mentioned conditions. After the optimal conditions determination, the actual sample extraction experiments were repeated 3 times and then the relative standard deviation average was calculated. Yield of the chlorogenic acid extraction from artichoke leaves was obtained as $9.8553 \pm 0.015 \mathrm{ppm}$. 
156

Y. Atıcı and I. Bulduk / Hacettepe J. Biol. \& Chem., 2020, 48 (2), 147-157

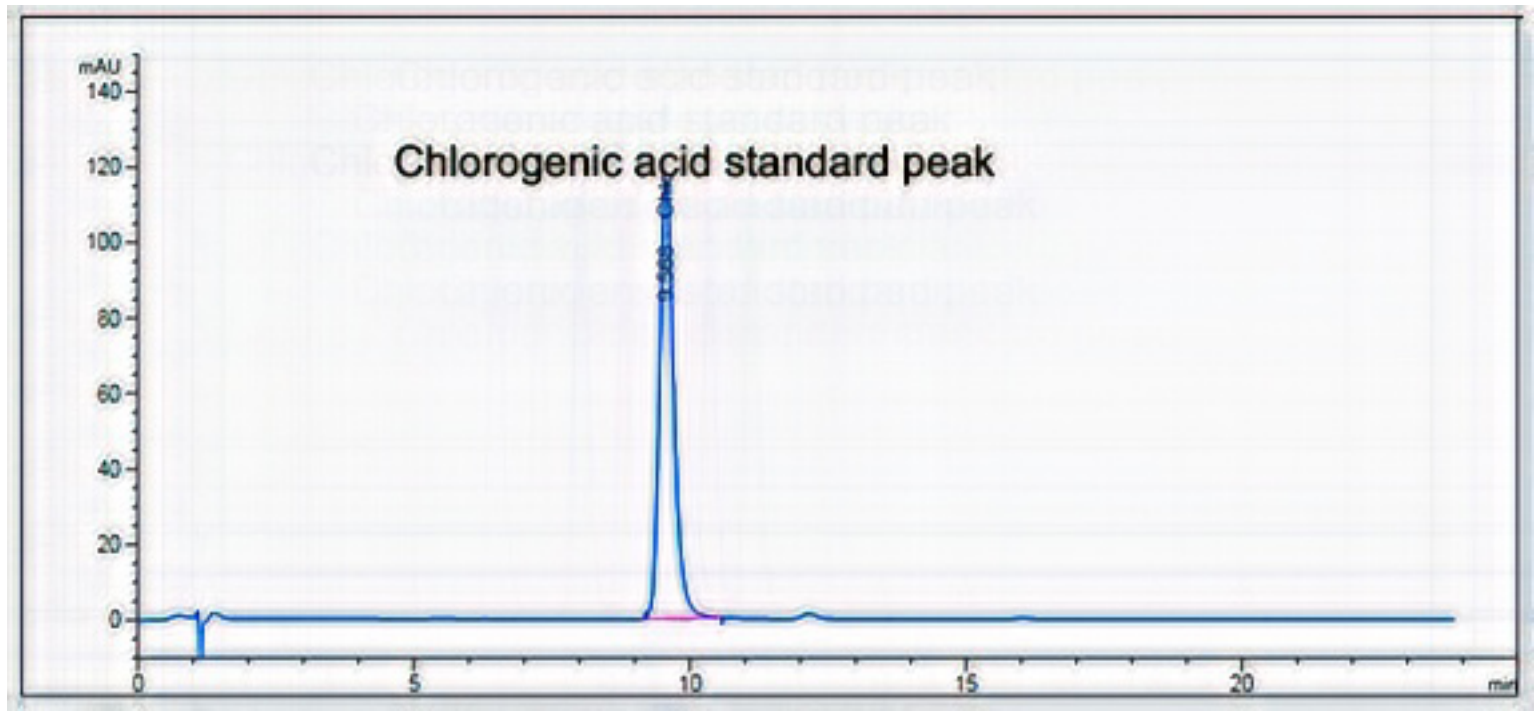

Figure 9. Chromatogram of standard chlorogenic acid.

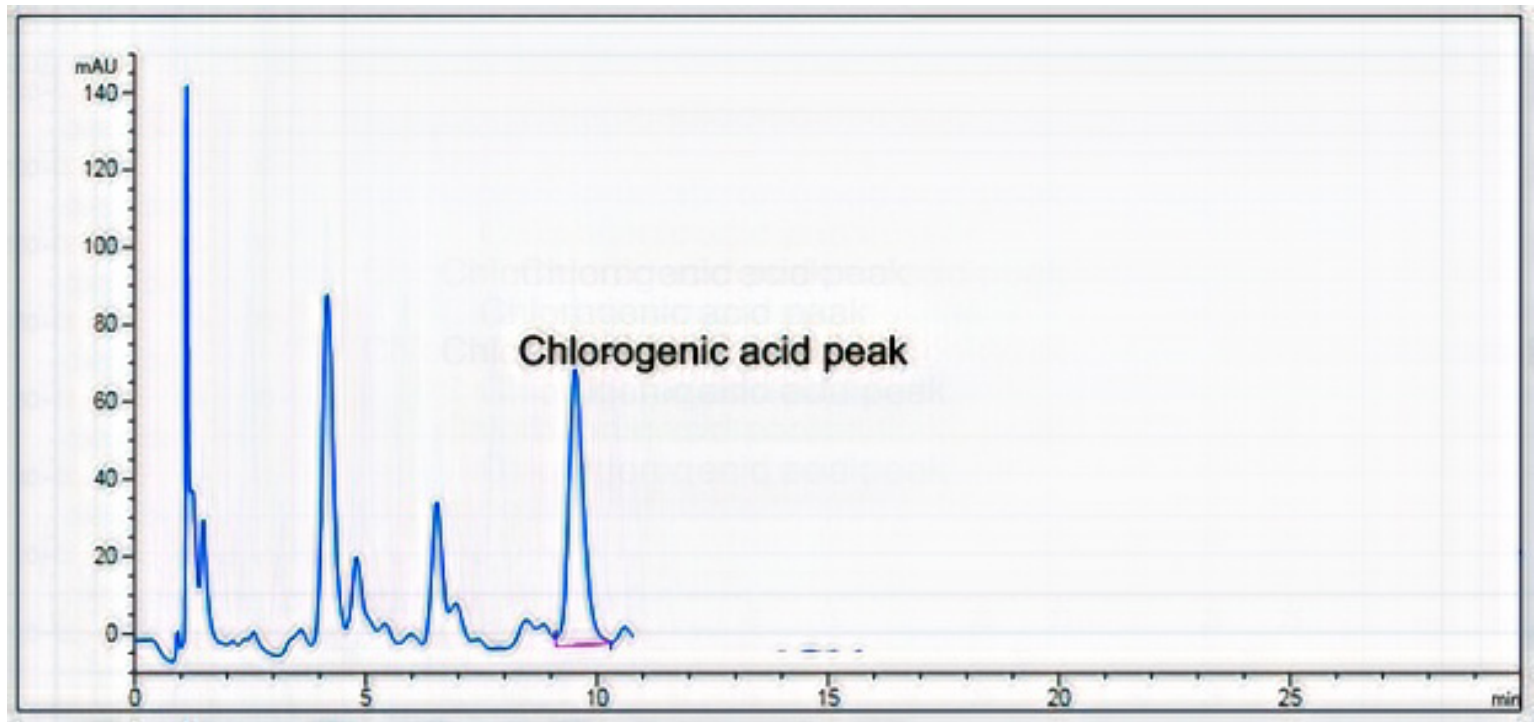

Figure 10. Chromatogram of chlorogenic acid which is derived artichoke leaf. 
Soxhlet extraction is more disadvantageous than ultrasonic assisted extraction due to the longer processing time and the large amount of organic solvent use. Furthermore, Soxhlet shows that an alternative method is needed because of the disadvantages of the extraction method such as solvent selectivity and difficult auto- 2 . mation [12]. In the case of pressurized liquid extraction, the sample can be pretreated freezing and drying before extraction. Furthermore, the high cost of cleaning 3. and the use of excess solvent are disadvantages of this extraction method, as well. In microwave assisted extraction method, the use of excess organic solvent makes this method a disadvantageous method. There are several disadvantages such as high investment cost and high energy requirement according to the fact that separation with supercritical fluids occurs at high pressu- 6 . re. Another neglected disadvantage, which is extremely important, is the most commonly used carbon dioxide [13].

In these results obtained according to the extraction of chlorogenic acid active ingredient ultrasonic assisted extraction (UAE) have shown can be an effective met- 9 . hod.

\section{References}

1. Y. Chen, Q. J. Yu, X. Li, Y. Luo, H. Liu, Extraction and HPLC characterisation of chlorogenic acid from tobacco residuals, Separ. Sci. Technol., 42 (2007) 3481-3492.

2. W. Shen, R. Qi, J. Zhang, Z. Wang, H. Wang, C. Hu, Y. Zhao, M. Bie, Y. Wang, Y. Fu, M. Chen, D. Lu, Chlorogenic acid inhibits LPS-induced microglial activation and improves survival of dopaminergic neurons, Brain Res. Bull., 88 (2012) 487-94.

3. H. Jang, H.R. Ahn, H. Jo, K.A Kim, E. Lee, K. Lee, S. Jung, C. Lee, Chlorogenic acid and coffee prevent hypoxia-induced retinal degeneration, J. Agric. Food Chem., 62 (2013) 182-191.

4. Q. J. Yu, X. Li , Y. Luo, H. Liu, Y.Chen, Extraction and HPLC characterisation of chlorogenic acid from tobacco residuals, Separ. Sci. Technol., 42 (2007) 3481-3492.

5. A. Ayelign, K. Sabally, Determination of chlorogenic acids (CGA) in coffee beans using HPLC, Amer. J. Res. Commun., 1 (2013) (78-91).

6. T. Cui, K. Nakamura, L. Ma, J.Z. Li, H. Kayahara, Analyses of arbutin and chlorogenic acid, the major phenolic constituents in oriental pear, J. Agric. Food Chem, 53 (2005) 3882-3887.

7. E. Zeiger, R. Tice, Chlorogenic acid and caffeic acid review of toxicological literatüre, Research Triangle Park, North Carolina, 1998.

8. A. Mustafa, C. Turner, Pressurized liquid extraction as a green approach in food and herbal plants extraction: A review, Analyt. Chimic. Acta, 703 (2011) 8-18.

9. G. E. P. Box, K. B. Wilson, On the experimental attainment of optimum conditions, J. Royal Statistic. Soc., 13 (1951) 1-45.

10. A. Farah, M. Monteiro, C.M.D.S. Lafay, Chlorogenic acids from green coffee extract are highly bioavailable in human, J. Nutrit., 138 (2008) 2309-2315.

11. H.M. Santos, J.L. Capelo, Trends in ultrasonic-based equipment for analytical sample treatment, Talanta, 73 (2007) 795-802.

12. J.L. Capelo, A.M. Mota, Ultrasonication for analytical chemistry, Curr. Analy. Chem., 1 (2005) 193-201.

13. D.L. Luthria, R. Biswas, S. Natarajan, Comparison of extraction solvents and techniques used for the assay of isoflavones from soybean Food Chem., 105 (2007) 325. 